\title{
A Development Strategy of O2O Business in China
}

\author{
Xu Tiansheng \\ Information College \\ Capital University of Economics and Business \\ Beijing, China
}

\author{
Zhang Jiong \\ Information College \\ Capital University of Economics and Business \\ Beijing, China
}

\begin{abstract}
This paper analyzes the concept, current development of $\mathrm{O} 2 \mathrm{O}$ business models in china. The characteristic of these models including advantages and existing problems are also discussed extensively. Through the analysis of successful cases of these business models, a new development strategy is proposed to improve the efficiency of China $\mathrm{O} 2 \mathrm{O}$ business model. It also can be used for $\mathrm{O2O}$ enterprises to make future business decision.
\end{abstract}

\section{Keywords-O2O; e-commerce; Development strategy}

\section{INTRODUCTION}

$\mathrm{O} 2 \mathrm{O}$ is online to offline, referring to the offline business opportunities by using the Internet, the offline business trading on the internet. This concept comes from the United States first. O2O concept is very broad, as long as the industry chain involves the online and the offline business, it is known as O2O. Many industries are currently exploring the O2O mode, after 2012, the Chinese O2O mode has developed very fast, and began to integrate the mobile devices and the local service. Since then the online E-commerce decided to open offline stores and the offline stores began to build online platform. This thesis mainly describe the concept, present situation, the advantage and the future of $\mathrm{O} 2 \mathrm{O}$ to make the $\mathrm{O} 2 \mathrm{O}$ mode in China have a better development.

\section{PRESENT SituATION OF O2O MODE'S DEVELOPMENT}

The concept of $\mathrm{O} 2 \mathrm{O}$ was put forward by AlexRampell in August 2010 and Ctrip is the earliest O2O mode in China. But early pattern only pays attention to the flow of information transfer, cash flow and the service flow generally realized offline. Follow-up, Dianping.com is the early practitioners of $\mathrm{O} 2 \mathrm{O}$ concept. The emergence of the group purchase mode, the information flow and cash flow through online at a stroke, commercial and service flows offline, marked the $\mathrm{O} 2 \mathrm{O}$ mode into a completely new stage in China, despite its development in China is not very desirable. But it is undeniable that the mode of the Group purchase will make $\mathrm{O} 2 \mathrm{O}$ concrete, $\mathrm{O} 2 \mathrm{O}$ will also push the industrial development forward .

The $\mathrm{O} 2 \mathrm{O}$ model of Chinese market has a large capacity, only the local life services on behalf of the market capacity will reach hundreds of billions of scale. Many enterprises have gradual tendency towards the $\mathrm{O} 2 \mathrm{O}$, such as Tencent "WeChat", Ali Alipay, Taobao business, Baidu Philharmonic live and LBS(location-based services) the establishment division, as well as traditional industry such as Wanda Group, Suning Commerce. These prove that today's market prospects for $\mathrm{O} 2 \mathrm{O}$ mode are good.

This research was supported by Level of Scientific Research Improving Project of Beijing Municipal Education Commission 2015.

\section{SPECIFIC ANALYSIS OF FOUR O2O OPERATING MODES}

The basic business logic of $\mathrm{O} 2 \mathrm{O}$ mode is that users in the online platform to pay in advance, and then to consume offline. Merchants track its marketing effect, business services and the experience of the resulting closed-loop process in the real time. It uses the "electronic market + to shop" mode, rather than "electronic market and logistics distribution" mode.

In China, O2O concept is hot; someone calls 2014 the first year of O2O. Some argue that the $\mathrm{O} 2 \mathrm{O}$ model is the upgrade version of $\mathrm{B} 2 \mathrm{C}$ mode, more emphasis on consumption experience. At present domestic to $\mathrm{O} 2 \mathrm{O}$ concept has been generalized, involved in the industrial chain of online and offline modes are called $\mathrm{O} 2 \mathrm{O}$ modes. Wyman brand director tchaikevtaz thinks, $\mathrm{O} 2 \mathrm{O}$ mode to conform to the three characteristics: have completely through online and offline platform, with the thinking mode of the Internet to run the two platforms, all for the center with the user. Information flow and cash flow through online implementation, commercial and service flows are realized offline.

In particular, the implementation of the $\mathrm{O} 2 \mathrm{O}$ mode is two basic ways and path: Online to Offline and Offline to Online. On this basis, the other two are derived from the implementation of the mode and path: Online to Offline to Online and Offline to Online to Offline. Actually each implementation way and the path is not absolutely isolated, but the interaction of online forms after fusion closed-loop, and form a continuous and complete $\mathrm{O} 2 \mathrm{O}$ mode. But for ease of reading $\mathrm{O} 2 \mathrm{O}$, it is subdivided into four kinds of operation modes.

\section{A. Mode 1:Online to Offline}

The so-called Online to Offline mode is the enterprise to set up an online platform first, based on the platform and entry, offline businesses flowing into the online marketing and trading.At the same time, the consumers offline can enjoy the corresponding offline service. This platform is the foundation of $\mathrm{O} 2 \mathrm{O}$ operation, should have a powerful resource flow exchanging capacity and have an ability of interaction between online and offline. In reality, many indigenous service companies have adopted to this model. Tencent, for example, with its accumulated resources flow aggregation and transformation ability and the economic base, building the $\mathrm{O} 2 \mathrm{O}$ platform ecosystem is the case.

On O2O layout, tencent has built up the tencent platform and set up the ecological $\mathrm{O} 2 \mathrm{O}$ chain : WeChat platform for big entrance, there is a Tencent Map backend. 
Such as WeChat payments, an integration among local living services; such as Dianping.com carrying on food services; such as DiDi app helping people taking a taxi; such as Gaopeng.com selling tickets of films, thus to build up the closed loop of $\mathrm{O} 2 \mathrm{O}$ interaction.

\section{B. Mode 2:Offline to Online}

The so-called offline to online mode is the enterprise to set up offline platform first, based on the platform of offline marketing, letting users enjoy the corresponding service experience. At the same time the offline business flow will go into the online platform and trading online, thus to promote offline to online interaction and form a closed loop. In this kind of $\mathrm{O} 2 \mathrm{O}$ mode, enterprises need to build two platforms, namely the offline entity platform and online Internet platform. In reality, the use of this $\mathrm{O} 2 \mathrm{O}$ mode is the majority in the materialization of enterprises; SuNing Yunshang's O2O platform built by the ecological system is the case.

At present,SuNing YunShang has more than 1600 stores offline and has platforms of cooperation in the other fields. Online, its SuNing.com network platform has covered the categories of traditional home appliance, 3c digital products, daily provisions and so on.
Su Ning puts forward "E-commerce+retailers+stores" operating model, through stores, PC and mobile phone terminal, it will be integrated between offline experience and online convenience. It will establish a new win-win mode for retail enterprises and consumers, suppliers and merchants. The road map is "one body two wings ": Internet retail as the main body; $\mathrm{O} 2 \mathrm{O}$ whole channel business and online\&offline open platform as the two wings.

\section{Mode 3:Online to Offline to Online}

The so-called online to offline to online mode is the enterprise to set up an online platform for marketing thus online business will flow into offline again to let users enjoy the service experience and then let users to trade online or consume online. In reality, a lot of group purchase websites, Ecommerce companies have adopted this $\mathrm{O} 2 \mathrm{O}$ mode, such as JD. In December 2013, JD determined the O2O mode to be one of the important strategies in the future. JD O2O ecological chain is: building JD.com first, it being as a platform for marketing, self-conducting logistics systems cooperating with the entity enterprises, letting the users enjoy the offline service and then urge users to make online transactions in JD.

TABLE I. THE VALUE OF FOUR O2O MODES AND IMPLEMENTATION WAYS

\begin{tabular}{|c|c|c|c|c|}
\hline & online to offline & offline to online & online to offline to offline & offline to online to offline \\
\hline $\begin{array}{c}\text { Typical } \\
\text { applications }\end{array}$ & $\begin{array}{c}\text { Tencent’s series of application: } \\
\text { WeChat + dianping.com + } \\
\text { Tencent } \\
\text { map+GaoPeng.com+DiDi taxi }\end{array}$ & $\begin{array}{l}\text { Suning Stores+Suning.com; } \\
\text { Guomei } \\
\text { Stores+Guomei.comWanDa } \\
\text { +BaiWanteng.com }\end{array}$ & $\begin{array}{l}\text { Manzuo.com, Dida Group, } \\
\text { Lashou.com , JD invest } \\
\text { Jingle net Dao Jia.com; } \\
\text { buyout TangJiu store. }\end{array}$ & $\begin{array}{l}\text { Papa John's pizza: through online } \\
\text { platforms and third-party APP the } \\
\text { users can find Papa John's stores } \\
\text { offline. First, the consumers need } \\
\text { to pay online, and then they can } \\
\text { go to Papa John's offline stores to } \\
\text { enjoy their services. }\end{array}$ \\
\hline Implement way & $\begin{array}{l}\text { The enterprise to set up an } \\
\text { online platform first, based on } \\
\text { the platform and entry, offline } \\
\text { businesses flowing into the } \\
\text { online marketing and trading. } \\
\text { At the same time, the } \\
\text { consumers offline can enjoy the } \\
\text { corresponding offline service. }\end{array}$ & $\begin{array}{l}\text { The enterprise to set up } \\
\text { offline platform first, based } \\
\text { on the platform of offline } \\
\text { marketing, letting users } \\
\text { enjoy the corresponding } \\
\text { service experience. At the } \\
\text { same time the offline } \\
\text { business flow will go into } \\
\text { the online platform and } \\
\text { trading online, thus to } \\
\text { promote offline to online } \\
\text { interaction and form a } \\
\text { closed loop. }\end{array}$ & $\begin{array}{l}\text { The enterprise to set up an } \\
\text { online platform for } \\
\text { marketing thus online } \\
\text { business will flow into } \\
\text { offline again to let users } \\
\text { enjoy the service experience } \\
\text { and then let users to trade } \\
\text { online or consume online. }\end{array}$ & $\begin{array}{l}\text { The enterprise to build the offline } \\
\text { platform for marketing first, then } \\
\text { import the offline commercial } \\
\text { flow into the online platform or } \\
\text { use the third-party online platform } \\
\text { leveraging national distribution } \\
\text { for online transactions, and then } \\
\text { let the users to enjoy the offline } \\
\text { spending experience. }\end{array}$ \\
\hline $\begin{array}{l}\text { Representation of } \\
\text { value }\end{array}$ & $\begin{array}{l}\text { Tecent open two API; Weichat } \\
\text { payment and Tecent map, offer } \\
\text { technological service to the } \\
\text { third-party service providers, } \\
\text { let them work well in the } \\
\text { Wetchat ecosystem chain }\end{array}$ & $\begin{array}{l}\text { It will be integrated } \\
\text { between offline experience } \\
\text { and online convenience. It } \\
\text { will establish a new win- } \\
\text { win mode for retail } \\
\text { enterprises and consumers, } \\
\text { suppliers and merchants. }\end{array}$ & $\begin{array}{l}\text { This mode can docking itself } \\
\text { IT system with offline } \\
\text { convenient stores' IT system } \\
\text { sharing the online traffic and } \\
\text { make precise marketing for } \\
\text { JD platform. }\end{array}$ & $\begin{array}{l}\text { Unify the order platform, user } \\
\text { experience and the supply chain, } \\
\text { so as to realize O2O’s whole } \\
\text { supply chain operations. }\end{array}$ \\
\hline
\end{tabular}

JD.com is a platform which mainly operates depending on itself and it has become a banner in the field of B2C. It is the starting point of $\mathrm{JD} \mathrm{O} 2 \mathrm{O}$ and $\mathrm{JD} \mathrm{O} 2 \mathrm{O}$ is relying on the platform of JD.com. In the offline world, on the one hand, JD has invested heavily to build logistics network for years, it has more than 1400 distribution stations and more than 15000 deliverymen, and this becomes JD O2O's backward advantage. On the other hand, cooperating with the offline entity shops, 
JD builds "1 hour local life circle" and it makes JD O2O directly "on the ground".

For laying solid foundation of offline services, filling the lack of proprietary offline store, JD intensifies the cooperation with the stores offline. In November 2013, JD cooperated with the TaiYuan local large-scale Tang Jiu convenience chain store, Tang Jiu build a selling zone in JD. The background system automatic matches consumers' address with the nearest convenience store to delivery. In March 2014, JD cooperated with more than 11000 convenient stores, covering many cities in China.

\section{Mode 4:Offline to Online to Offline}

The so-called Offline to Online to Offline mode is the enterprise to build the offline platform for marketing first, then import the offline commercial flow into the online platform or use the third-party online platform leveraging national distribution for online transactions, and then let the users to enjoy the offline spending experience. In this $\mathrm{O} 2 \mathrm{O}$ mode, the selected third-party platforms are generally readily available and they are influential social platforms, such as Wetchat, Dianping.com, and Weatao. Meanwhile, it can utilize many third-party platforms to attract traffic to realize their business goals.

As a chain restaurant brand, Papa John's pizza, got double-digit growth through online ordering mode and the take-away service accounted for $30 \%$. Its O2O ecological chain is: through online platforms and third-party APP the users can find Papa John's stores offline. First, the consumers need to pay online, and then they can go to Papa John's offline stores to enjoy their services. Specifically, Papa John currently has opened more than 4,000 chain restaurants in the world, which are their capital of competition. In the online area, on the one hand, Papa John designed APP, set up their own online ordering platform; on the other hand, use the third-party platform to attract traffic, for example Wetchat and Dianping.com.

After the completion of the $\mathrm{O} 2 \mathrm{O}$ layout, it will be online and offline integration in order to create O2O closed loop. Papa John's approach is to unify the order platform, user experience and the supply chain, so as to realize O2O's whole supply chain operations.

\section{O2O BUSINESS MODEL'S DEVELOPMENT STAGE}

To make O2O e-commerce model towards healthy, virtuous circle development, thus, the $\mathrm{O} 2 \mathrm{O}$ direction analysis needs to strengthen the key point in the process of $\mathrm{O} 2 \mathrm{O}$ model development.

\section{A. Fully strengthen the interaction between online and offline}

The essence of $\mathrm{O} 2 \mathrm{O}$ mode is to fully strengthen the interaction between online and offline to integrate online and offline into the whole industrial chain, so it should emphasize the combination of online and offline to make online marketing and offline experience perfectly.The union is to better meet the customer's needs and make the customers feel more comfortable so that it can create more valuable brand.

\section{B. Make $\mathrm{O} 2 \mathrm{O}$ operation mode diversed}

O2O operators can not only provide some surface, low technical services, but also consider to dig more potential, more competitive business mode. For example, we can provide house rental service, socializing car rental service, DIY clothes service and other diversified services; also the profit mode can become very flexible too. There are user-oriented fees, but also fees for merchants, more advertise to charge. So it is important to make strategies depending on the concrete condition in order to achieve a win-win situation.

In the operation aspect, $\mathrm{O} 2 \mathrm{O}$ operators can not only lock low-price development but also find some value-added services to help merchants make profits by virtue of their own media advantage. Many merchants are offering diversified business system, but because the propaganda is not in place, these services do not attract consumers. At this point, the $\mathrm{O} 2 \mathrm{O}$ operators must cooperate with the merchants together to make the diverse service better.

\section{C. make full use of the mobile Internet}

Compared with the traditional Internet e-commerce mobile Internet's user base is more huge, closer to the market and consumers. Merchants and enterprises can contact and win more customers at lower cost, do our business on the palms of consumers. Therefore, mobile business is more suitable for $\mathrm{O} 2 \mathrm{O}$ business applications, it will promote $\mathrm{O} 2 \mathrm{O}$ mode into the dominant force in a wider range of commercial life. App and LBS application have become common forms, operators can cooperate with mobile application providers to win huger user community. For example, developing and designing coupons for the goods or services; designing QR code of commodity information; realizing goods and service by mobile phone; Open brand zone on the weibo or take part in some hot spots of the activities involved in mobile phone on weibo.

\section{SUMMARY}

While there are high barriers to enter in, B2C and C2C market, supported by the development of logistics and express industry, has matured, it has great potential. Entrepreneurs are looking for a new model of this kind of e-commerce. $\mathrm{O} 2 \mathrm{O}$ is a new way to practice that. It goes beyond the narrow concept of industry and can be applied to various industries. It leads the overall business environment transformation and innovation. And the valve of $\mathrm{O} 2 \mathrm{O}$ is not only in the consumer terminal, but also in the industry chain structure. While $\mathrm{O} 2 \mathrm{O}$ lead enterprise operation going from single win to win-win. It is not only good for one enterprise but also for the upstream and downstream. It achieves the win-win for the whole business line.

In order to successfully operating $\mathrm{O} 2 \mathrm{O}$ model, it need to have enough offline chain shops, and customers should have much cognition for the model. This pattern not only brings changes in consumption thinking and service, but also puts forward a new challenge to the traditional electricity supplier. Operator should change the inherent thinking, take advantage of the accumulated internet resources, analyze large amounts data, realize the convenience of the mobile Internet, integrate online and offline resources, achieve a perfect docking and let 
user experience more satisfying. The $\mathrm{O} 2 \mathrm{O}$ can get a rational development.

\section{REFERENCES}

[1] Z. He "Business model analysis of personalized information service ecommerce”, Information Science, 2005 (08).

[2] G. Zong, L. Heng ,"strategy B2C in e-commerce”, E-commerce world, 2005 (11).

[3] W. Liang, G. Kuang, “an electronic exchange of value chain analysis”, Industrial technology economy, 2007 (11).

[4] N. Chen, C. Mi, "Third-party payment development analysis and recommendations”, Modern business, 2009 (35).

[5] Y. Cheng, "Rebuild our science and technology enterprise based ecommerce business model”, Hei Longjina technology and information, 2009 (33).

[6] J. Liu, "The traditional business to survive online”, Internet Week, 2010, (9): 30-31.

[7] X. Huang, "The traditional department store industry restructures in online shopping boom”, Sales and marketing Management Edition, 2011, (3): 90-93.

[8] B. Zhang, "the shop online and the store offline will be long-term coexistence”, Market Watch, 2011, (4): 50. 